\title{
Proteomic identification of quality factors for oocytes in the Pacific oyster Crassostrea gigas
}

\author{
Charlotte Corporeau ${ }^{a,}{ }^{*}$, Gwenaëlle Vanderplancke ${ }^{a}$, Myrina Boulais ${ }^{a}$, Marc Suquet ${ }^{a}$, Claudie \\ Quéré $^{a}$, Pierre Boudry ${ }^{a}$, Arnaud Huvet ${ }^{a}$, Stéphanie Madec ${ }^{b}$
}

\footnotetext{
${ }^{a}$ Ifremer, Laboratoire des sciences de l'Environnement Marin (UMR 6539, LEMAR) 29280 Plouzané, France

${ }^{b}$ Laboratoire Universitaire de Biodiversité et Ecologie Microbienne (EA3882), IFR148 ScInBioS, Université Européenne de Bretagne, ESMISAB, Technopôle de Brest Iroise, 29280 Plouzané, France
}

*: Corresponding author : Charlotte Corporeau, Tel.: + 332982247 64; fax: + 332982246 53. email address : charlotte.corporeau@ifremer.fr

\begin{abstract}
:
We used a 2-DE proteomic approach to identify abundant proteins linked to oocyte quality in the Pacific oyster Crassostrea gigas, an economically important bivalve. Oocyte quality of 14 females was estimated by recording fertilisation and early developmental success until D-larval stage under controlled conditions. Proteins that were differentially expressed between females showing high or low oocyte quality were identified by nano-liquid chromatography tandem mass spectrometry. Twelve upaccumulated spots associated with low quality oocytes revealed 10 distinct proteins, including vitellogenin - breakdown products and metabolic enzymes. Eight up-accumulated spots from high quality oocytes revealed 6 distinct proteins, including chaperone molecules and cell-cycle control proteins. This is the first proteomic study dedicated to oocytes in C. gigas. Our results improve current knowledge about protein factors associated with oocyte quality in this species, and our understanding of the proteomic processes involved in their developmental competence.
\end{abstract}

\section{Graphical abstract}
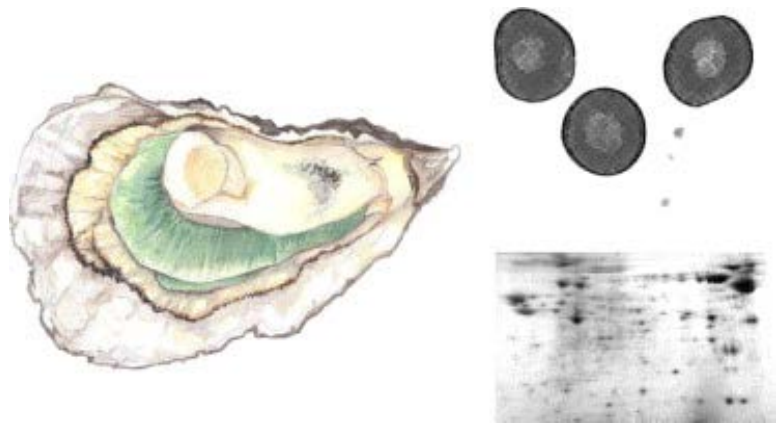

\section{Highlights}

- 14 Pacific oyster females were fertilised in vitro by a common pool of spermatozoa. Individual variability of D-larva yields was due to the intrinsic quality of oocytes. Two-dimensional proteomics identified protein factors for oocyte quality.

\section{Abbreviations}

MS, mass spectrometry; HPLC, high performance liquid chromatography; 2-DE, two-dimensional electrophoresis.

Keywords: Marine bivalves; Crassostrea gigas; Oocyte quality; Proteomics 


\section{Introduction}

Most marine bivalve production in Europe still relies on the collection of wild seed, but global change has led to an increasingly unpredictable seed supply. The case of the Pacific oyster in France illustrates this problem (http://wwz.ifremer.fr/velyger). Bivalve hatcheries have thus grown up to complement the wild seed supply for the shellfish industry, and also offering new opportunities for genetic improvement [1]. Today, Pacific oyster is one of the most important bivalve species produced by artificial reproduction [2], but reproductive success and profitability of hatcheries remain inconsistent. This is partly due to variability of oocyte quality [3], which is defined as the potential of oocytes to produce a viable progeny [4]. Previous studies on Pacific oyster have assessed oocyte quality by diameter [5] or total lipid content [6]. Novel approaches, such as two-dimensional proteomics, could become powerful tool to study oocyte quality in bivalves, as in other species such as vertebrates and sea bass [7].

A fully grown oocyte accumulates large amounts of maternal messenger RNA and proteins [8]. Early embryonic development, before the major wave of embryonic genome activation, is believed to be dependent on these maternal factors, essential for fertilisation, first cleavage and embryonic genome activation [9]. Many studies demonstrate that maternal history modulates the expression and function of proteins in oocytes in a way that will impact offspring metabolism and survival [10] [11]. For example, the direct modulation of oocyte signalling pathways using pharmacological compounds or hormones can affect fertilisation success and developmental potential [12] [13]. In Dicentrarchus labrax, recent studies have indicated the contribution of some oocyte-specific proteins to the regulation of egg quality [7] [14].

To find out which maternal protein factors could be related to oocyte quality in the Pacific oyster Crassostrea gigas, we conducted a proteomic study using two-dimensional electrophoresis (2-DE). The 2-DE methodology was chosen to identify main changes in abundant and soluble oocyte proteins without a priori. This methodology does not allow to obtain a comprehensive description of the whole oocyte proteome. Recent developments in genomic resources for Pacific oyster [15] allowed us to identify proteins according to their MS/MS spectra obtained by tandem mass spectrometry.

\section{Material and methods}

\subsection{Biological material}

Twenty two-year-old oysters (mean weight $\pm S D=58.7 \pm 10.5 \mathrm{~g}$ ) were collected in February from the Aber Benoît Estuary (Finistère, France) and transferred to the nearby Ifremer' facilities in Argenton. In order that the oysters achieved gonad maturation under controlled conditions, they were fed two microalgae, Isochrysis galbana Tahiti clone and Chaetoceros gracilis, at a ratio of 2:100 (dry mass algae to fry mass oyster) and maintained in 600-L tanks of $1-\mu \mathrm{m}$-filtered sea water at $17^{\circ} \mathrm{C}$, with continuous sea water renewal [16]. After a conditioning period of 2 months, the oysters were sacrificed and a 2-3 mm cross section of the visceral mass was made in front of the pericardic region of each individual for later histological examination of the gonadic tissue. The left section of each gonad was rapidly rinsed in sea water at $20{ }^{\circ} \mathrm{C}$ and oocytes were immediately collected by stripping after scarification and filtration at $20 \mu \mathrm{m}$ to remove cell debris [17]. The oocytes were then incubated in $2 \mathrm{~L}$ of filtered sea water and counted under light microscope.

\subsection{Oocyte diameter measurement}

For each female, a $50 \mu \mathrm{l}$ sample of oocytes was collected with a $200 \mu \mathrm{l}$ pipette tip and deposited in a 24 well micro-plate $\left(\mathrm{Nunc}^{\mathrm{TM}}\right.$ ) filled up with $1 \mu \mathrm{m}$-filtered seawater at $20^{\circ} \mathrm{C}$. 
Immediately after collection, oocyte pictures were taken using a camera (SONY 3 CCD Color Video Camera) connected to a microscope (Leica, DMIL, x10 objective). Oocyte diameter was measured using the Image $J$ software ( $n=30$ oocytes / female).

\subsection{Oocyte fertilization and D-larva yield}

Oocytes were incubated less than 1 hour in sea water at $20^{\circ} \mathrm{C}$ before their fertilisation. Fertilisation followed a standard protocol as described in [17]. Briefly, for each female, triplicates of 25,000 collected oocytes were fertilised in vitro by a common mixed pool of spermatozoa collected from 3 males, using a non-limiting 800 sperm to egg ratio. To assess the percentage of oocytes of each female that was successfully fertilised and developed through the early embryo stages, the D-larva yields were quantified under a light microscope $48 \mathrm{~h}$ after fertilisation.

\subsection{Total protein extraction from oocytes}

For total protein extraction, $2 \times 10^{\wedge}$ oocytes were sampled by filtration at $20 \mu \mathrm{m}$ into a $50 \mathrm{ml}$ Falcon tube and collected by gentle centrifugation at $1000 \mathrm{rpm}$ for $2 \mathrm{~min}$ at $4{ }^{\circ} \mathrm{C}$. The conservation of oocyte morphology was checked under a light microscope. To solubilize proteins, $5 \mathrm{ml}$ lysis buffer $(150 \mathrm{mM} \mathrm{NaCl}, 10 \mathrm{mM}$ Tris, $1 \mathrm{mM}$ EDTA, $1 \mathrm{mM}$ EGTA, 1\% Triton $\mathrm{X}-100,0.5 \%$ lgepal, 1 tablet of complete EDTA free protease inhibitor cocktail in $25 \mathrm{ml}$ of buffer, phosphatase inhibitor cocktail III) were added. Total proteins were then extracted as described by [18]. Briefly, total protein lysates were obtained after homogenization with an Ultra-Turrax and soft centrifugation at $3,000 \mathrm{~g}$ for $1 \mathrm{~h}$ at $4{ }^{\circ} \mathrm{C}$ for elimination of lipids. The lipid layer was in the upper phase and was easily eliminated by pipeting. The interphase (around $4,5 \mathrm{ml}$ ) which contained the proteins was collected and the small pellet of cell debris was left. The interphase was then centrifugated at $10,000 \mathrm{~g}$ for $45 \mathrm{~min}$ at $4{ }^{\circ} \mathrm{C}$ to ensure total lipid depletion. The interphase (around $4 \mathrm{ml}$ ) was collected, aliquoted and stored at $-80^{\circ} \mathrm{C}$. For each lysate, the total protein content was quantified using a DC protein assay (Bio-Rad, Hercules, CA, USA) with 96-well micro-plates (NuncTM) in a micro-plate reader (Bio-Tek® SynergyTM HT) and KC4 v3 software to compare results with a calibration curve of standard proteins (Bovine Serum Albumin) provided with the DC protein assay kit.

\subsection{Two-dimensional electrophoresis}

Based on histological analyses, we selected 14 females in stage 3 of gonadic maturation (ripe oocytes as described in [19]) for protein analysis. For each female and oocyte sample, an equal amount $(500 \mu \mathrm{g})$ of total protein lysate was precipitated and desalted to limit the presence of non-protein impurities such as salts, buffers, or remanent lipids in the samples before IsoElectroFocusing (IEF). Precipitation and desalting were performed by adding 2 volumes of $20 \%$ TCA on ice for $20 \mathrm{~min}$. The samples were then centrifuged at $12,000 \mathrm{~g}$ for $15 \mathrm{~min}$ and the pellet washed 5 times with $80 \%$ acetone in $0.05 \mathrm{M} \mathrm{Tris}-\mathrm{HCl} \mathrm{pH} 8$. Proteins were resuspended in a rehydrating solution (DeStreak, GE Healthcare) containing $1 \%$ Immobilized $\mathrm{pH}$ Gradient ampholytes (IPG) and placed at room temperature for $1 \mathrm{~h}$ before IEF. A pool of 6 oocyte samples was used as an internal control of experimental repeatability. The IEF dimension was conducted on a Bio-Rad Protean IEF Cell system ${ }^{\mathrm{TM}}$ (Bio-Rad, Hercules, CA, USA). Total proteins were loaded onto each strip (Immobiline DryStrip $\mathrm{pH} 3-10,11 \mathrm{~cm}, \mathrm{GE}$ Healthcare), and passive rehydratation allowed at room temperature overnight using mineral oil to prevent sample evaporation. The IEF was carried out at $20^{\circ} \mathrm{C}$ in four steps: a calibration step at $100 \mathrm{~V}$ constant voltage for $3 \mathrm{~h}$, an active hydration step at $300 \mathrm{~V}$ constant voltage for $1 \mathrm{~h}$, a continuous increase in voltage up to 8000 $\mathrm{V}$ over $8 \mathrm{~h}$ to start migration, and a migration step at $8000 \mathrm{~V}$ constant voltage for 11 hours. Before the second dimension, the IPG strip was rehydrated for $15 \mathrm{~min}$ in a solution for saturation containing $6 \mathrm{M}$ urea, $2 \%$ SDS, $30 \%$ glycerol and $1 \%$ DTT in $0.05 \mathrm{M}$ Tris- $\mathrm{HCl} \mathrm{pH}$ 8.8. The strip was then further equilibrated for $15 \mathrm{~min}$ in a similar buffer, in which DTT was 
replaced with $2.5 \%$ iodoacetamide to alkylate the proteins. For the second dimension of the 2-D electrophoresis, 8-16 \% gradient SDS-PAGE precast gels (Bio-Rad, Hercules, CA, USA) were used, run on a Criterion system (Bio-Rad, Hercules, CA, USA). The gels were loaded with broad range SDS-PAGE molecular weight markers. Migration was realized at $200 \mathrm{~V}$ constant voltage for $1 \mathrm{~h}$. After 2-DE, protein spots were stained by Coomassie blue coloration (PlusOne Coomassie Tablets, PhastGel Blue R-350, GE Healthcare) and washed in $7 \%$ acetic acid, $30 \%$ methanol solution. For image analysis, 16-bit level images of the gels were captured in tagged image file format (TIFF) and analysed using Progenesis ${ }^{\mathrm{TM}}$ SameSpots v1.5 software (Nonlinear Dynamics, Newcastle upon Tyne, UK). A composite image of the 14 gels (one for each studied individual) was generated, spots were detected automatically and all spot volumes were normalized using built-in algorithms. After automatic spot detection, spot boundaries were manually edited and artefacts on the images removed. Normalized spot intensities were obtained for each spot on the images. A comparison was made between the spots on the two groups of 7 gels (high versus low quality oocytes).

\subsection{In-gel digestion for mass spectrometry}

Twenty Coomassie blue-stained spots of interest were excised from the SDS-PAGE and processed for trypsin digestion. Excised spots were washed twice with milliQ water and destained for $15 \mathrm{~min}$ in $100 \mathrm{mM} \mathrm{NH}_{4} \mathrm{HCO}_{3}$ and $50 \%$ acetonitrile (ACN), then dehydrated in 100 $\% \mathrm{ACN}$. They were re-hydrated in $100 \mathrm{mM} \mathrm{NH}_{4} \mathrm{HCO}_{3}$ and again dehydrated in $100 \% \mathrm{ACN}$. Excised spots were air-dried and in-gel digestion was performed overnight at $37{ }^{\circ} \mathrm{C}$ with modified trypsin (Promega, Charbonnières-les-Bains, France) at $12.5 \mathrm{ng} / \mu \mathrm{L}$ in $70 \mu \mathrm{L}$ of 50 $\mathrm{mM} \mathrm{NH}_{4} \mathrm{HCO}_{3}$. The resulting tryptic peptides were extracted from the gel spots by sequential incubation in ACN / water / formic acid, 70:30:0.1 (v/v/v), then $100 \% \mathrm{ACN}$ and, finally, ACN / water / formic acid, 70:30:0.1 (v/v/v). The tryptic digests were then concentrated by vacuum centrifugation to reach a final volume of $30 \mu \mathrm{L}$.

\section{Nano LC-MS/MS analysis}

LC-MS/MS analyses were performed on a nano-HPLC system (Ultimate 3000, Dionex, Jouyen-Josas, France) coupled on-line with an Esquire HCT Ultra PTM Discovery mass spectrometer (Bruker Daltonics, Bremen, Germany) equipped with a nanoflow electrospray ionisation source and an ion trap analyzer. Tryptic digests were concentrated by injecting 22 $\mu \mathrm{L}$ volumes into a Dionex C18 PepMap300 trapping reverse phase pre-column (5 $\mu \mathrm{m}, 300 \AA$ / $5 \mathrm{~mm} \times 300 \mu \mathrm{m}$ inner diameter). Peptides were then passed onto a Dionex C18 PepMap100 reverse phase nano-column $(3 \mu \mathrm{m}, 100 \AA / 150 \mu \mathrm{m} \times 75 \mu \mathrm{m}$ inner diameter) and eluted with a gradient of $2 \%$ to $90 \%$ ACN in $0.05 \%$ formic acid for 52 min at a flow rate of $250 \mathrm{~nL} / \mathrm{min}$. The mass spectrometer was operated in positive ionization mode with an analytical scan range of $\mathrm{m} / \mathrm{z} 150-2500 \mathrm{Th}$. Ion accumulation time was automatically set with an ion charge control (ICC) target of 90000 to avoid space charge effects. EsquireControl ${ }^{\mathrm{TM}}$ software (Bruker Daltonics) automatically alternated MS and MS/MS acquisitions in an exclusion dynamic mode (the seven most intense ions were selected and excluded from further selection for a duration of $0.25 \mathrm{~min}$ ). MS/MS data were acquired using a $4 \mathrm{~m} / \mathrm{z}$ unit ion isolation window and a $1.2 \mathrm{~V}$ fragmentation amplitude.

\subsection{Databases searches}

MS/MS data files were used to query Gigasdatabase, a database containing 82,312 contigs (Database ID: http://public-contigbrowser.sigenae.org:9090/Crassostrea gigas/, [15]), using the Mascot algorithm (Mascot server v2.2; http://www.matrixscience.com). Search parameters were as follow: one missed cleavage allowed, carbamidomethylation of cysteins set as fixed modification, methionine oxidation set as variable modification, $0.25 \mathrm{Da}$ 
precursor tolerance and 0.5 Da fragment tolerance. Peptide identifications were accepted if the individual ion Mascot scores were above the identity threshold (an ion score $f-10 \times \log (p)$ where $p$ is the probability that the observed match is a random event). In case of ambiguous assignments (one compound fitted to more than one peptide), peptides were accepted based on the peptide score, meaning that the peptide sequence with the highest score was accepted and it did not matter if the protein was contained in the list. The matching of identified peptides to proteins was performed with the ProteinExtractor algorithm [20], so that every protein reported was identified by at least one peptide with a significant ion Mascot score (above the identity threshold), that could not be mapped to a higher-ranking protein already in the result list. This means that the protein lists provided contain only those proteins and protein variants that could be distinguished directly by MS/MS. Homology searches obtained from the Gigasdatabase were validated or sometimes modified using xblasting in $\mathrm{NCBI}$. This one by one annotation of the selected ESTs therefore improved their annotation compared to the automatic annotation done for the Gigasdatabase contigs, probably due to some false stop codons coming from sequencing errors and/or from mutations known to be very abundant in C. gigas [21]. For every protein reported in the identification list, a combined protein score (metascore) was calculated from the peptide scores using the ProteinExtractor algorithm. The calculated peptide mass and pl of the translated ESTs were evaluated on the EXPASY website (http://web.expasy.org/compute_pi/) [22].

\subsection{Statistical analysis}

Results were expressed as mean \pm standard deviation (SD). Percentages were square-root transformed and statistical analyses were performed using Student's test at a significance level of $p=0.05$. For 2-DE pattern analyses, three biological replicates for each female and two analytical replicates for each protein sample were compared between high quality and low quality oocytes. Differences in spot abundance were statistically evaluated after normalisation $(p<0.05)$, using the Progenesis Stats tool from the Progenesis SameSpots $\odot$ software package (Prodigy (C)).

\section{Results and discussion}

\subsection{D-Larva-D yield}

When the histological examination of the gonads showed female oysters to be in the process of oocyte resorption [19], these individuals were excluded from all analyses. As a result, 14 females at stage 3 of gonadic maturation (i.e. mature oocytes with apparent nuclei and nucleoli) were selected for our study. A high variability between individuals was observed for D-larva development, ranging from 1 to $58 \%$ (Fig. 1). Because the environmental conditions and experimental procedures were kept uniform between females, this variation was most likely to be due to the intrinsic quality of oocytes of each female. The mean D-larva yield observed in this study is close to values reported for a standardised experimental fertilisation protocol established for Pacific oyster oocytes [17]. Such individual variability is commonly observed in molluscs [3] [23] as well as in fish [24]. The females were split into two groups, each containing 7 individuals, between which there is a significant difference for early developmental success of fertilised oocytes $(p<0.001)$ : a high quality group $(52 \% \pm 5$ as mean \pm SD) and a low quality group (11\% \pm 9 as mean \pm SD). No statistical difference was obtained in the oocyte diameter between high quality group $(77.7 \mu \mathrm{m} \pm 10.1$ as mean $\pm \mathrm{SD})$ and low quality group $(71.1 \mu \mathrm{m} \pm 4.5$ as mean $\pm \mathrm{SD})$. 


\subsubsection{Proteomic analysis of differentially expressed proteins}

Spots analysed were strongly detectable using classical Coomassie staining of standard 2-D gels. Fig. 2A and B illustrates gels of high and low quality females, respectively. A comparison was made between 7 proteome maps from high quality females and 7 proteome maps from low quality females. Gels were obtained from triplicates of biological sample for each female and were done in duplicates as recommended in Sinha and Chattopadhyay (2011) [25]. The analysis of 2-DE pattern revealed 106 resolved spots corresponding to abundant soluble proteins extracted from oocytes. Among them, only 20 spots presented significant oocyte quality-dependent changes (Fig.3), showing a statistically significant down $(n=12)$ or up-accumulation $(n=8)$ in high quality oocytes. These differentially expressed spots $(n=20 ; p<0.05)$ were excised and subsequently digested with trypsin. All selected spots $(n=20)$ produced peptides suitable for identification using nano-liquid chromatography coupled tandem mass spectrometry with significant hits $(100 \%$ identification success). Table 1 shows the list of the 20 spots identified at a significant level of confidence by MS/MS which corresponded to 16 distinct proteins. The resolution of protein separation obtained using classical 2-D proteomic methodology led sometimes to the identification of several proteins in the same spot (Table 1). Average fold change, represented by increase in spot intensity, varied from 1.1 to 1.8 for low quality, and from 1.1 to 1.9 for high quality oocytes (see supplementary data). In this study, we did not obtain any de novo spots typical of high or low quality.

This work is the first 2-DE proteome study dedicated to oocytes of Pacific oyster. Proteomic approach with unsequenced organisms remains a challenge but, with 82,312 EST contigs currently available for $C$. gigas [15], we were able to identify proteins on the basis of mass spectrometry results. Similar proteomic studies were recently published for two other oyster species in which genomic information is not as abundant: to study proteome from hemolymph of Sydney rock oyster Saccostrea glomerata and proteome from shell and mantle of the Pearl oyster Pinctada margaritifera [26] [27]. The abundant maternal proteins that are easily detectable through proteomics might have a variety of important functions during oocyte maturation and early development [28]. Here we analysed the oocyte proteins stained with Coomassie blue that identified abundant proteins, such as vitellogenins, but made it difficult to identify proteins expressed at low levels [29] [30]. Although we did not provide a comprehensive description of the whole proteome changes related to oocyte quality, based on the differing nature of the proteins identified in the low and high quality oocytes, we can discuss the possible physiological meaning of their variation.

\subsection{Up-accumulated proteins in low quality oocytes}

Twelve spots up-accumulated in low quality oocytes corresponded to ten distinct proteins (Table 1). Among them, five vitellogenin $(\mathrm{Vg})$ protein members were identified that corresponded to $\mathrm{Vg}$-breakdown products, likely related to oocyte ageing. We also identified four enzymes, suggesting the influence of intracellular metabolism on oocyte quality and subsequent embryonic development. The last, protein we identified was one involved in cytoskeletal dynamics.

\subsubsection{Yolk protein vitellogenins}

Vertebrate and invertebrate $\mathrm{Vg}$ proteins (homodimers of $250-600 \mathrm{kDa}$ ) are large phospholipoglycoprotein precursors that are cleaved to generate yolk storage proteins traditionally regarded as the energy reserve for nourishment of the developing embryos [31]. In Pacific oyster, $\mathrm{Vg}$ are internalized by developing oocytes and proteolytically cleaved during the blastula stage to generate vitellin, which is later used as a nutrient source by developing embryo [32] [33]. 
The oyster protein vitellogenin Vg (Genbank accession \# AB084783; [34]), with a predicted molecular weight of $179.2 \mathrm{kDa}$ and $\mathrm{pl}$ of 9.2 , was isolated from several up-accumulated spots from low quality oocytes. It had an apparent molecular weight around $200 \mathrm{kDa}$ with pl of 9.2, as expected (Table 1; spots \# 2 and 3 ) but showed different results in the other spots: 20,50 and $90 \mathrm{kDa}$ (Table 1, spots \# 1; 8 and 4) with pl of 6.2, 7.0, or 10, respectively. These molecular weights suggest that $\mathrm{Vg}$ had been cleaved into small parts and that these spots were cleavage products of the whole $\mathrm{Vg}$ protein of $179.2 \mathrm{kDa}$. This idea is supported by in silico analysis of $\mathrm{Vg}$ using the FindPept tool at EXPASY (http://web.expasy.org/compute_pi/) [22], which predicted this size of $\mathrm{Vg}$ peptides, and the fact that spots and predicted peptides both contained the unique matching peptides for $\mathrm{Vg}$ in our MS/MS identification. In the stink bug Plautia crossota stali, the cleavage of a $\mathrm{Vg}$ protein of $140 \mathrm{kDa}$ was demonstrated in oocytes by bands of $23,37,50,70$ and $90 \mathrm{kDa}$ in a western - blot, identified using anti- $\mathrm{Vg}$ antibody [35]. This breakdown of $\mathrm{Vg}$-containing yolk granules was obtained when degeneration of mature vitellogenic oocytes was induced by starvation, indicating that $\mathrm{Vg}$ was targeted by proteases when oocytes began resorption [35] [36]. In our study, females showing clear patterns of resorption in a histological examination were excluded from our proteomic analysis, but we can not ascertain whether biochemical mechanisms involved in oocyte resorption could have begun in low quality oocytes. Further studies should be necessary to address this question by comparison of proteome between low quality and resorbed oocytes.

However, we can hypothesized that low quality of oocytes in Pacific oyster involved the same mechanisms observed for oocyte ageing in other species. Indeed, in rainbow trout, Vgbreakdown products were accumulated during ageing of post-ovulatory oocytes, which can last 2 to 3 weeks, and oocyte ageing was associated with a progressive egg-viability decrease [37]. A proteomic analysis of the coelomic fluid showed that post-ovulatory ageing of oocytes increased the amount of $\mathrm{Vg}$ fragments in the coelomic fluid and could indicate egg-quality defects [37]. These $\mathrm{Vg}$ fragments came from the leakage of some oocyte components and might be due to increased proteolytic activities in poor-quality oocytes; these might include cathepsin D activity, as suggested in sea bream [38]. Oocyte protease activities might thus play a major role in oocyte quality.

Moreover, electrophoretic mobility shifts in 2-DE gels revealed that $\mathrm{Vg}$ protein might also contain post-translational modifications, as demonstrated in oocytes of Mya arenaria, rainbow trout, and Green bug, Plautia crossota stali [39] [37] [36]. For the four other $\mathrm{Vg}$ members up-accumulated in low quality oocytes - three vitellogenin precursors and Vitellogenin-2 - post-translational modifications were suggested since these were identified in spots with a higher molecular weight that the one predicted (Table 1; spots \# 4;5; 6 and 7). Indeed, Vg members have potential sites for lipidation, glycosylation and phosphorylation, and post-translational modifications can alter the biochemical properties and function of $\mathrm{Vg}$ in oocytes, as demonstrated in the clam Mya arenaria [39]. In fact, hyperphosphorylation led to particular chemical composition of $\mathrm{Vg}$ that changed $\mathrm{Vg}$-binding properties and induced dysfunction of $\mathrm{Vg}$ in the oocyte and developing embryo [39].

\subsubsection{Up-accumulation of metabolic enzymes}

In our study, Isocitrate DeHydrogenase (IDH) was up-accumulated in low quality oocytes (Table 1, spots \# 8 and 9) and could reflect a particular type of redox metabolism. IDH is known to be involved in energy homeostasis, which is crucial for fertility in mouse oocytes [40]. In a comparison of two lines of Pacific oysters selected to be resistante (R) or susceptible (S) to summer mortality (for further details, see [41]), the mRNA encoding IDH was over-expressed in the gonad of resistant oysters and was related to their greater capacity to detoxify reactive oxygen species (ROS) [42]. ROS are known to be deleterious as they modify biological molecules, including lipids, proteins and nucleic acids, inducing abnormal development and embryonic lethality in mouse [43]. Further studies are necessary 
to better understand the biological significance of IDH protein up-accumulation and redox metabolism in oocytes, and how differences in these processes lead to low D-larva yields.

Two enzymes involved in de novo purine synthesis were up-accumulated in the low quality oocytes: PhosphoribosylAminolmidazole carboxylase (PAl carboxylase; Table 1, spot \# 8) and ATP synthase subunit $\alpha$ (Table 1, spot \# 10). Synthesis of purines and phosphoinositides is involved in spontaneous and progesterone-induced nuclear maturation in Bufo arenarum oocytes [44], while maturation in mouse oocytes is induced in vivo when purine metabolism is altered [45] [46]. These studies point to the critical role of purine metabolism in the maintenance of oocyte maturation.

We also found up-accumulation of a DyP-type peroxidase in low quality oocytes (Table 1, spot \# 11). In the sea urchin, such an "ovoperoxidase" is stored within the oocyte and helps to block polyspermy at fertilisation by modifying the surface envelope of the eggs [47] [48]. This peroxidase could be spermicidal [49] and could also lead to the production of a hard fertilisation membrane capable of blocking the entry of additional sperm and/or killing sperm in the vinicity of the fertilised egg. We can hypothesize that the Dyd-type peroxidase upaccumulation we observed in low quality oocytes could have altered the oocyte envelope in oyster, thus affecting fertilisation success.

\subsubsection{Up-accumulation of cofilin}

Cofilin is a small protein of $15 \mathrm{kDa}$ (Table 1, spot \# 12), belonging to the family of actindepolymerizing factors that changes cytoskeletal dynamics and regulates cell motility, cytokinesis, and calcium signalling pathways [50]. When injected into starfish oocytes, cofilin altered the spatio-temporal pattern of physiologically occurring $\mathrm{Ca}(2+)$ signals essential for oocyte maturation and fertilisation [50]. In Xenopus oocytes, the protein cofilin is localised in the cytoplasm and its function is regulated at the post-translational level. At fertilisation, dephosphorylated cofilin migrates along the membrane to ensure the subsequent cleavage of blastomeres [51]. Taken together, we can suppose that up-accumulation of cofilin in low quality oocytes of Pacific oyster could indicate an abnormal regulation of cytoskeletal dynamics and $\mathrm{Ca}(2+)$ signalling that could lead to early embryo failure.

\subsubsection{Up-accumulated proteins in high quality oocytes}

Eight spots up-accumulated in the high quality oocytes corresponded to six distinct proteins (Table 1). Among them we identified vitellogenin (with a different size than in low quality oocytes), three chaperone molecules involved in folding and maturation of nascent polypeptides, and two proteins involved in cell-cycle control.

\subsubsection{Yolk protein vitellogenins}

In high quality oocytes, two Vitellogenin (Genbank accession \# AB084783) cleavage products with individual molecular weights of $70 \mathrm{kDa}$ and $40 \mathrm{kDa}$ were up-accumulated (Table 1; spots \# 13 and 14). Some protease activities during oogenesis [47] might thus ensure specific $\mathrm{Vg}$ breakdown related to the status of oocytes and with consequences for fertilisation and the developmental success [33].

\subsubsection{Chaperone molecules}

We observed a higher amount of Heat-Shock Cognate protein of $70 \mathrm{kDa}$ (HSC70) in high quality oocytes (Table 1; spots \# 14 and 15). These molecular chaperone proteins bind to nascent polypeptides, promote correct protein folding and prevent the aggregation of nonnative and misfolded proteins [52] [53]. In mouse, activation of the zygotic genome initiates 
an accumulation of embryonic transcripts in the early two-cell embryo that needs heat-shock proteins to ensure the accurate translation and folding of nascent proteins [54]. Interestingly, HSC70 was seen to sustain the block to polyspermy in amphibian oocytes [55] and viability of bovine eggs is related to the amount of constitutive HSC70, which has protective effects against oxidative stress, temperature and $\mathrm{pH}$ fluctuation, and exposure to visible light [56]. In Pacific oyster oocytes, the up-accumulation of HSC70 could be related to better folding of proteins in two cell embryos, and better protection of oocytes and early embryos directly exposed to such environmental factors in the sea water.

Cyclophilin, a protein known to catalyze protein folding in cooperation with heat-shock protein [57] [58] was also up-accumulated in high quality oocytes (Table 1, spots \# 6; 7 and 8). This is a peptidylprolyl isomerase that belongs to the immunophilin family, and could thus be advantageous for the viability and immune protection of eggs and early embryos of Pacific oyster. Protein Disulfide Isomerase (PDI) is also a chaperone molecule up-accumulated in high quality oocytes (Table 1; spots \# 16). PDI catalyzes the rearrangement of disulfide bounds in proteins, particularly $\mathrm{Vg}$ [59]. In mouse, PDI is one of the highly abundant proteins localised at the surface of the mature oocyte plasma membrane (oolemma) [29], that is essential for the sperm-egg fusion at fertilisation [60]. In oyster, up-accumulation of PDI could reflect a better capacity of oocytes to produce $\mathrm{Vg}$ maturation products and/or control sperm fusion.

\subsubsection{Cell-cycle control}

14-3-3 $\varepsilon$ protein was up-accumulated in high quality oocytes (Table 1; spot \# 17). 14-3-3 $\varepsilon$ protein belongs to a highly conserved acidic protein family expressed in oocytes [61] [62] that can interact with over 200 target proteins involved in a variety of cellular processes including regulation of cell cycle, metabolism and protein trafficking [63]. Today, little is known about 14-3-3 $\varepsilon$ function in oocytes, but it has been suggested that 14-3-3 proteins inhibit G2/M progression to hold the cell in prophase arrest in mammalian and amphibian oocytes [64].

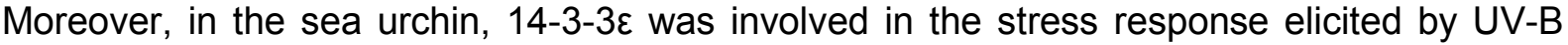
radiation in early embryo at the gastrula stage by promoting embryo survival [65]. Upaccumulation of $14-3-3 \varepsilon$ could thus be related to cell-cycle control in oocytes and better protection of embryos in Pacific oyster.

Proliferative Cell Nuclear Antigen (PCNA) was also up-accumulated in high quality oocytes (Table 1; spot \# 17). PCNA is a nuclear protein that helps the processivity of DNA replication and is involved in cellular processes such as cell-cycle control, base-excision repair and apoptotic pathways. In the gonadic tissue of Pacific oyster, PCNA expression was observed to increase during oogenesis [66] [67]. PCNA might be a maternal factor and its accumulation in high quality oocytes could be linked with the processivity of DNA synthesis during early development. In fact, recent and increasing information becomes available on PCNA in the gonad of Pacific oyster whose expression was exclusively restricted to germinal cells [66]. PCNA thus appears as a good candidate to construct an enzyme-linked immunosorbent assay to monitor oocyte quality between females.

\section{Conclusions}

Females Pacific oysters do not all produce oocytes of equal quality. Using a 2-DE proteomic approach, we identified several proteins that were differentially accumulated according to oocyte quality. Characterization of these proteins provided important insight into the mechanisms of early development in this marine bivalve. Future studies will search for environmental factors and maternal effects that might regulate the amounts of oocyte proteins produced, in order to improve our understanding of their variation under natural or controlled conditions (e.g. in oyster hatcheries). 


\section{Acknowledgments}

We are grateful to C. Mingant, I. Quéau and L. Lebrun, from the Ifremer' experimental station in Argenton, for broodstock and algae management and also thank the staff of the Proteomics Core Facility Biogenouest, Inserm U1085, Rennes, France. We thank H. McCombie for her help with editing the English. This study was supported by REPROSEED EU Grant No. 245119 (http://wwz.ifremer.fr/reproseed).

\section{Supplementary data}

The proteomic identification data (.dat files) were converted and submitted to the EBI (European Bioinformatics Institute: www.ebi.ac.uk/) [68] and are accessible via the PRIDE repository (http://www.ebi.ac.uk/pride/startBrowse.do) under the project name: "Qualityseed" (Accession numbers: 22028-22047), with reviewer access (username: review69532 and password: \$aeWKCFw). 


\section{References}

[1] Boudry P. Genetic variation and selective breeding in hatchery-propagated molluscan shellfish. Burnell $G$ and Geoff $A$ (eds): New technologies in aquaculture: improving production efficiency, quality and environmental management Wodd head Publishing Limited, Cambridge, UK. 2009:87-108.

[2] Helm MM, Bourne N, Lovatelli A. Hatchery culture of bivalves. A practical manual. . FAO Fisheries Technical Papers $N^{\circ} 471$ Food and Agriculture Organization of the United Nations, Rome. 2004:177 pp.

[3] Boudry P, Collet B, Cornette F, Hervouet V, Bonhomme F. High variance in reproductive success of the Pacific oyster (Crassotrea gigas; Thunberg) revealed by microsatellite-based parentage analysis of multifactorial crosses. Aquaculture. 2002;204:283-96.

[4] Kjorsvik E, Mangor-Jensen A, Holmefjord I. Egg quality in fishes. Advances in Marine Biology. 1990;26:71-113.

[5] Lango-Reynoso F, Chavez-Villalba J, Cochard J, Le Pennec M. Oocyte size, a means to evaluate the gametogenetic development of the Pacific oyster Crassotrea gigas. Aquaculture. 2000;190:183-99.

[6] Massapina C, Joaquim S, Matias D, Devauchelle N. Oocyte and embryo quality in Crassotrea gigas (Portuguese strain) during a spawning period in Algarve, South Portugal. Aquatic Living Resources. 1999;12:327-33.

[7] Crespel C, Rime H, Fraboulet E, Bobe J, Fauvel C. Egg quality in domestical and wild seabass Dicentrarchus labrax: a proteomic analysis. Cybium. 2008;32:205.

[8] Wrenzycki C, Herrmann D, Niemann H. Messenger RNA in oocytes and embryos in relation to embryo viability. Theriogenology. 2007;68 Suppl 1:S77-83.

[9] Li L, Zheng P, Dean J. Maternal control of early mouse development. Development. 2010;137:859-70.

[10] Chan LL, Sebert SP, Hyatt MA, Stephenson T, Budge H, Symonds ME, et al. Effect of maternal nutrient restriction from early to midgestation on cardiac function and metabolism after adolescent-onset obesity. Am J Physiol Regul Integr Comp Physiol. 2009;296:R145563.

[11] Heerwagen MJ, Miller MR, Barbour LA, Friedman JE. Maternal obesity and fetal metabolic programming: a fertile epigenetic soil. Am J Physiol Regul Integr Comp Physiol. 2010;299:R711-22.

[12] Aquila S, Rago V, Guido C, Casaburi I, Zupo S, Carpino A. Leptin and leptin receptor in pig spermatozoa: evidence of their involvement in sperm capacitation and survival. Reproduction. 2008;136:23-32.

[13] Aquila S, Guido C, Santoro A, Gazzerro P, Laezza C, Baffa MF, et al. Rimonabant (SR141716) induces metabolism and acquisition of fertilizing ability in human sperm. $\mathrm{Br} J$ Pharmacol. 2010;159:831-41.

[14] Bobe J, Labbe C. Egg and sperm quality in fish. Gen Comp Endocrinol. 2010;165:53548.

[15] Fleury E, Huvet A, Lelong C, de Lorgeril J, Boulo V, Gueguen Y, et al. Generation and analysis of a 29,745 unique Expressed Sequence Tags from the Pacific oyster (Crassostrea gigas) assembled into a publicly accessible database: the GigasDatabase. BMC Genomics. 2009;10:341.

[16] Fabioux C, Pouvreau S, Le Roux F, Huvet A. The oyster vasa-like gene: a specific marker of the germline in Crassostrea gigas. Biochem Biophys Res Commun. 2004;315:897904.

[17] Song Y, Suquet M, Quéau I, Lebrun L. Setting of a procedure for experimental fertilisation of Pacific oyster Crassostrea gigas oocytes. Aquaculture. 2009;287:311-4.

[18] Le Foll C, Corporeau C, Le Guen V, Gouygou JP, Berge JP, Delarue J. Long-chain n-3 polyunsaturated fatty acids dissociate phosphorylation of Akt from phosphatidylinositol 3'kinase activity in rats. Am J Physiol Endocrinol Metab. 2007;292:E1223-30. 
[19] Steele S, Mulcahy M. Gametogenesis of the oyster Crassotrea gigas in southern Ireland. J Mar Biol Assoc UK. 1999;70:673-86.

[20] Thiele H, Glandorf J, Hufnagel P, Korting G, Bluggel M. Managing Proteomics data: from generation and data warehousing to central data repository. J Prot Bioinf. 2008;1:485-507.

[21] Sauvage C, Bierne N, Lapegue S, Boudry P. Single Nucleotide polymorphisms and their relationship to codon usage bias in the Pacific oyster Crassostrea gigas. Gene. 2007;406:1322.

[22] Gasteiger E HC, Gattiker A, Duvaud S, Wilkins MR, Appel RD, Bairoch A. Protein Identification and Analysis Tools on the ExPASy Server. (In) John M. Walker (ed): The Proteomics Protocols Handbook, Humana Press-Copyright Humana Press 2005.

[23] Dong Q, Huang C, Eudeline B, Tiersch T. Systematic factor optimization for cryopreservation of diploid Pacific oyster Crassostrea gigas. Cryobiology. 2005;51:176-97.

[24] Salze G, Tocher D, Roy W, Robertson D. Egg quality determinants in cod (gadus morhua L.): egg performance and lipids in eggs from farmed and wild broodstock. Aquaculture research. 2005;36:1-12.

[25] Sinha R, Chattopadhyay S. Changes in the leaf proteome profile of Mentha arvensis in response to Alternaria alternata infection. J Proteomics. 2011;74:327-36.

[26] Simonian M, Nair SV, Nell JA, Raftos DA. Proteomic clues to the identification of QX disease-resistance biomarkers in selectively bred Sydney rock oysters, Saccostrea glomerata. Journal of Proteomics. 2009;73:209-17.

[27] Joubert C, Piquemal D, Marie B, Manchon L, Pierrat F, Zanella-Cleon I, et al. Transcriptome and proteome analysis of Pinctada margaritifera calcifying mantle and shell: focus on biomineralization. BMC Genomics. 2010;11:613.

[28] Massicotte L, Coenen K, Mourot M, Sirard MA. Maternal housekeeping proteins translated during bovine oocyte maturation and early embryo development. Proteomics. 2006;6:3811-20.

[29] Calvert ME, Digilio LC, Herr JC, Coonrod SA. Oolemmal proteomics--identification of highly abundant heat shock proteins and molecular chaperones in the mature mouse egg and their localization on the plasma membrane. Reprod Biol Endocrinol. 2003;1:27.

[30] Bantscheff M, Schirle M, Sweetman G, Rick J, Kuster B. Quantitative mass spectrometry in proteomics: a critical review. Anal Bioanal Chem. 2007;389:1017-31.

[31] Zhang S, Wang S, Li H, Li L. Vitellogenin, a multivalent sensor and an antimicrobial effector. Int J Biochem Cell Biol. 2011;43:303-5.

[32] Li Q, Osada M, Suziki T, Mori M. Changes in vitellin during oogenesis and effect of estradiol on vitellogenensis in the Pacific oyster Crassostrea gigas. Invert Reprod Dev. 1998;33:87-93.

[33] Li Q, Osada M, Suzuki T, Sato M, Mori K. Degradation of vitellin during embryonic and larval development in the Pacific oyster Crassostrea gigas Invert Reprod Dev. 1998;33:1-9.

[34] Matsumoto T, Nakamura AM, Mori K, Kayano T. Molecular characterization of a cDNA encoding putative vitellogenin from the Pacific oyster Crassostrea gigas. Zoolog Sci. 2003;20:37-42.

[35] Kotaki T. Oosorption in the stink bug, Plautia crossota stali: Induction and vitellogenin dynamics. J Insect Physiol. 2003;49:105-13.

[36] Kotaki T. The fate of vitellogenin and site of protein degradation during oosorption in the brown-winged Green bug, Plautia crossota stali. Formosan Entomol. 2006;26:99-108.

[37] Rime H, Guitton N, Pineau C, Bonnet E, Bobe J, Jalabert B. Post-ovulatory ageing and egg quality: a proteomic analysis of rainbow trout coelomic fluid. Reprod Biol Endocrinol. 2004;2:26.

[38] Carnevali O, Mosconi G, Cardinali M, Meiri I, Polzonetti-Magni A. Molecular components related to egg viability in the gilthead sea bream, Sparus aurata. Mol Reprod Dev. 2001;58:330-5.

[39] Gagne F, Blaise C, Pellerin J, Gauthier-Clerc S. Alteration of the biochemical properties of female gonads and vitellins in the clam Mya arenaria at contaminated sites in the Saguenay Fjord. Mar Environ Res. 2002;53:295-310. 
[40] Dumollard R, Ward Z, Carroll J, Duchen MR. Regulation of redox metabolism in the mouse oocyte and embryo. Development. 2007;134:455-65.

[41] Boudry P, Dégremont L, Haffray P. The genetic basis of summer mortality in Pacific oyster spat and potential for improving survival by selective breeding in France. . In Samain JF \& McCombie H (eds): Summer mortality of Pacific oyster Crassostrea gigas - The Morest Project Quae Editions, Versailles, France. 2008:153-96.

[42] Huvet A, Herpin A, Degremont L, Labreuche Y, Samain JF, Cunningham C. The identification of genes from the oyster Crassostrea gigas that are differentially expressed in progeny exhibiting opposed susceptibility to summer mortality. Gene. 2004;343:211-20.

[43] Ufer C, Wang CC. The Roles of Glutathione Peroxidases during Embryo Development. Front Mol Neurosci. 2011;4:12.

[44] Zelarayan L, Oterino J, Sanchez Toranzo G, Buhler MI. Involvement of purines and phosphoinositides in spontaneous and progesterone-induced nuclear maturation of Bufo arenarum oocytes. J Exp Zool. 2000;287:151-7.

[45] Downs SM, Eppig JJ. Induction of mouse oocyte maturation in vivo by perturbants of purine metabolism. Biol Reprod. 1987;36:431-7.

[46] Downs SM. Induction of meiotic maturation in vivo in the mouse by IMP dehydrogenase inhibitors: effects on the developmental capacity of ova. Mol Reprod Dev. 1994;38:293-302.

[47] LaFleur GJ, Jr., Horiuchi Y, Wessel GM. Sea urchin ovoperoxidase: oocyte-specific member of a heme-dependent peroxidase superfamily that functions in the block to polyspermy. Mech Dev. 1998;70:77-89.

[48] Sugano Y, Muramatsu R, Ichiyanagi A, Sato T, Shoda M. DyP, a unique dyedecolorizing peroxidase, represents a novel heme peroxidase family: ASP171 replaces the distal histidine of classical peroxidases. J Biol Chem. 2007;282:36652-8.

[49] Smith DC, Klebanoff SJ. A uterine fluid-mediated sperm-inhibitory system. Biol Reprod. 1970;3:229-35.

[50] Nusco GA, Chun JT, Ercolano E, Lim D, Gragnaniello G, Kyozuka K, et al. Modulation of calcium signalling by the actin-binding protein cofilin. Biochem Biophys Res Commun. 2006;348:109-14.

[51] Abe H, Obinata T, Minamide LS, Bamburg JR. Xenopus laevis actin-depolymerizing factor/cofilin: a phosphorylation-regulated protein essential for development. J Cell Biol. 1996;132:871-85.

[52] Delelis-Fanien C, Penrad-Mobayed M, Angelier N. Molecular cloning of a cDNA encoding the amphibian Pleurodeles walt $70-\mathrm{kDa}$ heat-shock cognate protein. Biochem Biophys Res Commun. 1997;238:159-64.

[53] Corporeau CD, Angelier N, Penrad-Mobayed M. HSP70 is involved in the control of chromosomal transcription in the amphibian oocyte. Exp Cell Res. 2000;260:222-32.

[54] Bensaude O, Babinet C, Morange M, Jacob F. Heat shock proteins, first major products of zygotic gene activity in mouse embryo. Nature. 1983;305:331-3.

[55] Smith GB, Umbach JA, Hirano A, Gundersen CB. Interaction between constitutively expressed heat shock protein, Hsc 70, and cysteine string protein is important for cortical granule exocytosis in Xenopus oocytes. J Biol Chem. 2005;280:32669-75.

[56] Korhonen K, Sjovall S, Viitanen J, Ketoja E, Makarevich A, Peippo J. Viability of bovine embryos following exposure to the green filtered or wider bandwidth light during in vitro embryo production. Hum Reprod. 2009;24:308-14.

[57] Matouschek A, Rospert S, Schmid K, Glick BS, Schatz G. Cyclophilin catalyzes protein folding in yeast mitochondria. Proc Natl Acad Sci U S A. 1995;92:6319-23.

[58] Rassow J, Mohrs K, Koidl S, Barthelmess IB, Pfanner N, Tropschug M. Cyclophilin 20 is involved in mitochondrial protein folding in cooperation with molecular chaperones Hsp70 and Hsp60. Mol Cell Biol. 1995;15:2654-62.

[59] Liao M, Boldbaatar D, Gong H, Huang P, Umemiya R, Harnnoi T, et al. Functional analysis of protein disulfide isomerases in blood feeding, viability and oocyte development in Haemaphysalis longicornis ticks. Insect Biochem Mol Biol. 2008;38:285-95. 
[60] Ellerman DA, Myles DG, Primakoff P. A role for sperm surface protein disulfide isomerase activity in gamete fusion: evidence for the participation of ERp57. Dev Cell. 2006;10:831-7.

[61] Mhawech P, Benz A, Cerato C, Greloz V, Assaly M, Desmond JC, et al. Downregulation of 14-3-3sigma in ovary, prostate and endometrial carcinomas is associated with $\mathrm{CpG}$ island methylation. Mod Pathol. 2005;18:340-8.

[62] De S, Marcinkiewicz JL, Vijayaraghavan S, Kline D. Expression of 14-3-3 protein isoforms in mouse oocytes, eggs and ovarian follicular development. BMC Res Notes. 2012;5:57.

[63] Mhawech P. 14-3-3 proteins--an update. Cell Res. 2005;15:228-36.

[64] Pirino G, Wescott MP, Donovan PJ. Protein kinase A regulates resumption of meiosis by phosphorylation of Cdc25B in mammalian oocytes. Cell Cycle. 2009;8:665-70.

[65] Russo R, Zito F, Costa C, Bonaventura R, Matranga V. Transcriptional increase and misexpression of 14-3-3 epsilon in sea urchin embryos exposed to UV-B. Cell Stress Chaperones. 2010;15:993-1001.

[66] Franco A, Jouaux A, Mathieu M, Sourdaine P, Lelong C, Kellner K, et al. Proliferating cell nuclear antigen in gonad and associated storage tissue of the Pacific oyster Crassostrea gigas: seasonal immunodetection and expression in laser microdissected tissues. Cell Tissue Res. 2010;340:201-10.

[67] Jouaux A, Heude-Berthelin C, Sourdaine P, Mathieu M, Kellner K. Gametogenic stages in triploid oysters Crassostrea gigas: Irregular locking of gonial proliferation and subsequent reproductive effort. J Exp Mar Biol Ecol. 2010;395:162-70.

[68] Barsnes H, Vizcaino JA, Eidhammer I, Martens L. PRIDE Converter: making proteomics data-sharing easy. Nat Biotechnol. 2009;27:598-9. 
Figure 1

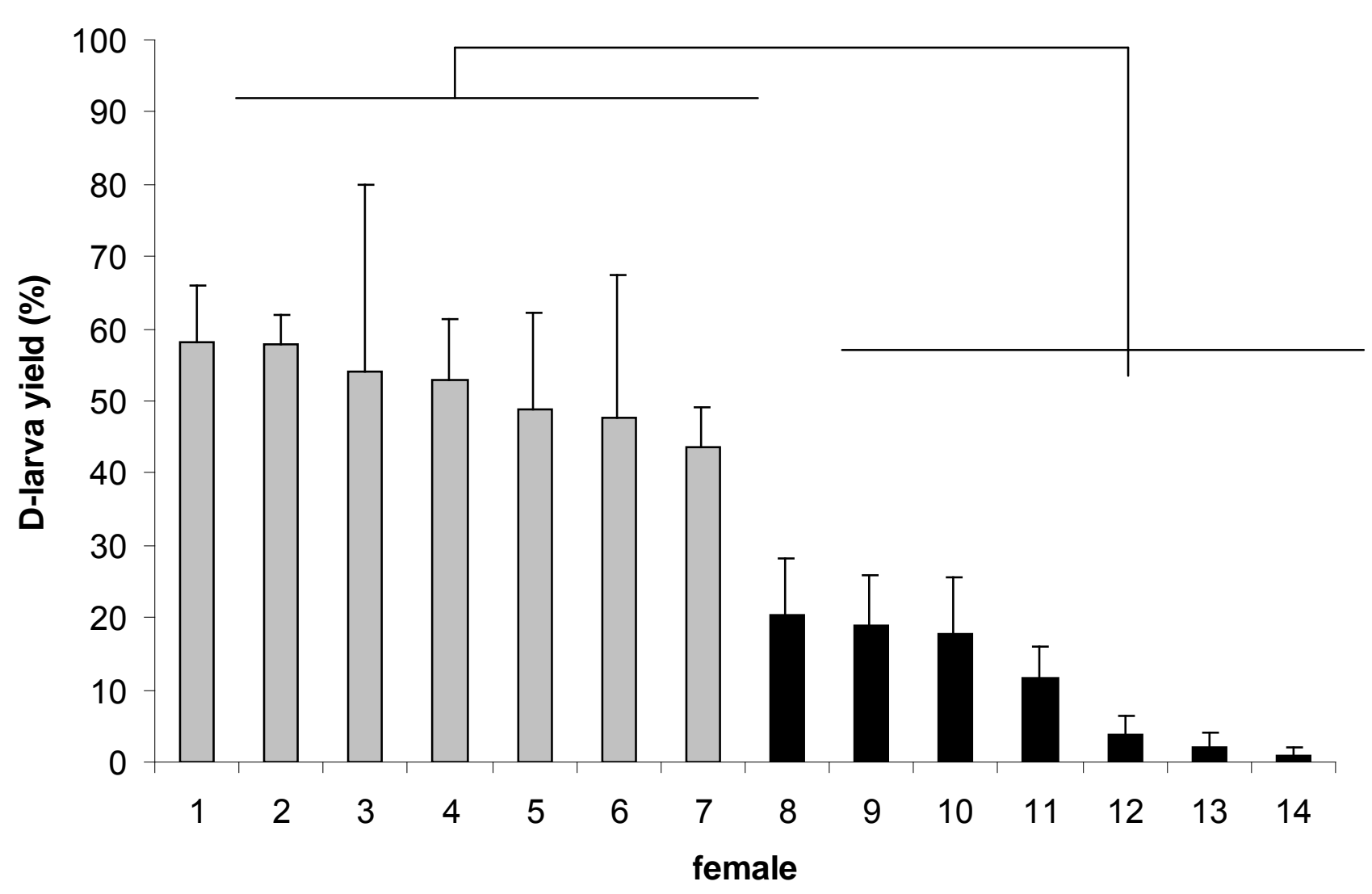

Figure 1: Individual D-larva yield (mean \pm SD) obtained from 14 females Pacific oysters Crassostrea gigas divided into two groups: high quality (grey bars) and low quality (black bars) oocytes $(p<0.001)$. Results are expressed as the percentage of oocytes that reached D-larval stage 48 hours after fertilisation. 
Figure 2
A (High)
B (Low)
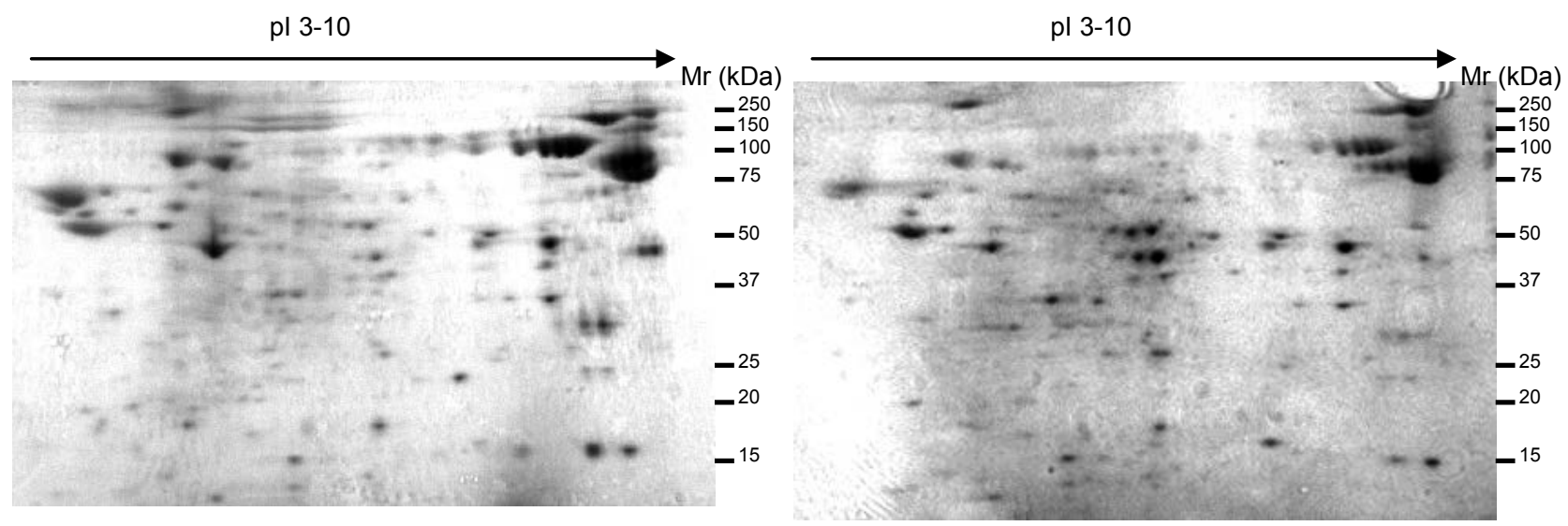

Figure 2: Gels of a 2-DE protein profile of high (A) or low (B) quality oocytes collected from female Pacific oysters. Results were obtained by separating $500 \mu \mathrm{g}$ of protein samples on a $11 \mathrm{~cm} \mathrm{pH} \mathrm{3-10} \mathrm{strip} \mathrm{followed} \mathrm{by} \mathrm{SDS-PAGE.} \mathrm{The} \mathrm{gels} \mathrm{were} \mathrm{stained} \mathrm{by} \mathrm{Coomassie} \mathrm{blue}$ coloration. Mr: molecular marker. 
Figure 3.

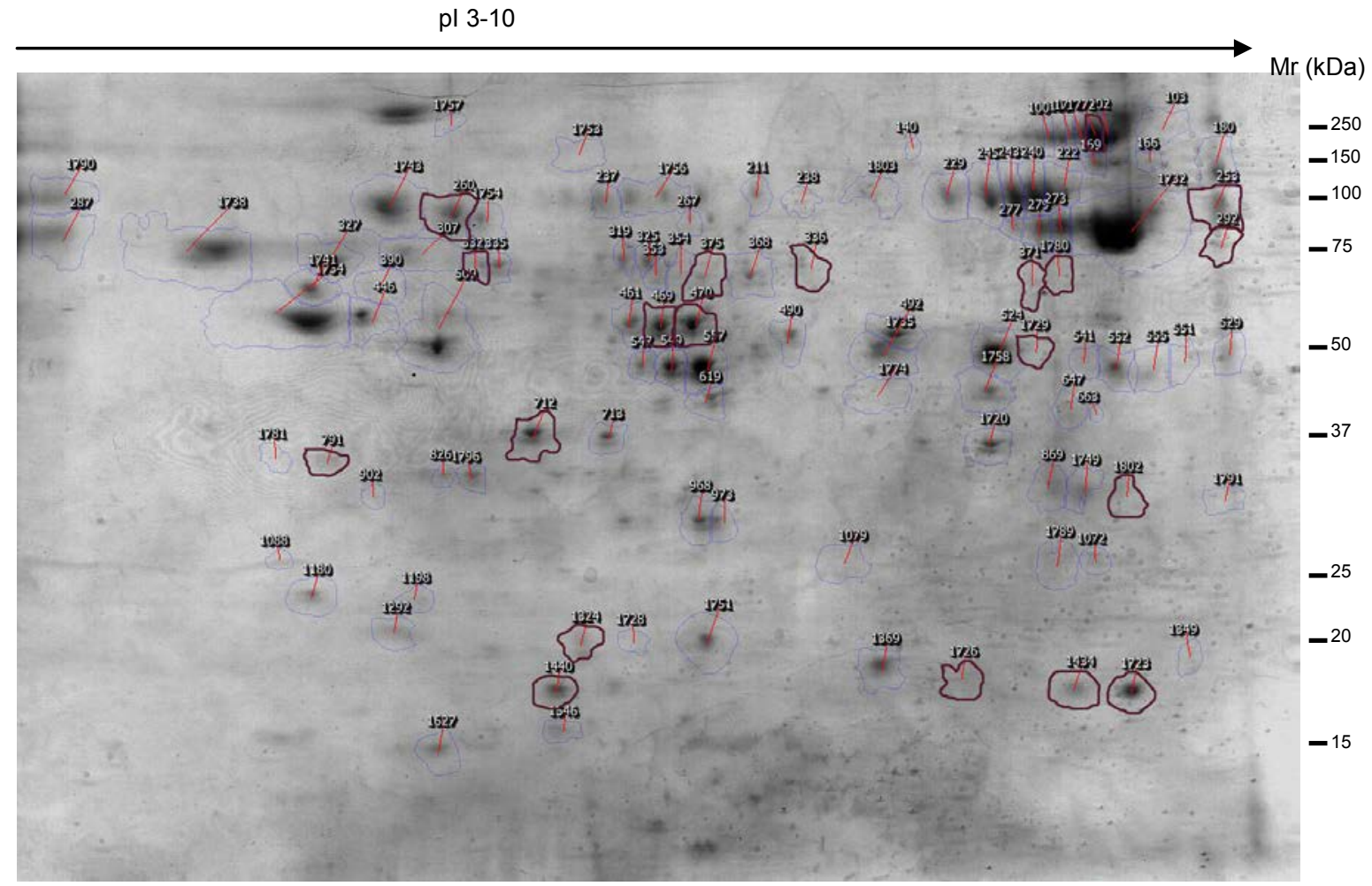

Figure 3: Reference image showing a gel of low quality oocytes. Resolved spots are marked with corresponding spot number and excised spots were encircled in brown. When a spot is identified, the name of the protein is shown in Table 1 and details of the corresponding mass spectrometry data are given in the Supplementary data. Mr: molecular marker. 
Table 1. Identified proteins up-accumulated in low or high quality oocytes from Pacific oyster.

\begin{tabular}{|c|c|c|c|c|c|c|c|c|c|}
\hline \begin{tabular}{|c|} 
serial \\
number \\
\end{tabular} & $\begin{array}{c}\text { spot } \\
\text { number }\end{array}$ & $\begin{array}{c}\text { average fold } \\
\text { change }\end{array}$ & protein annotation [organism] & $\begin{array}{c}\text { Genbank accession } \\
\text { number }\end{array}$ & $\begin{array}{c}\mathrm{Mr}(\mathrm{kDa}) / \mathrm{pl} \\
\text { theoritical }\end{array}$ & $\begin{array}{l}\mathrm{Mr}(\mathrm{kDa}) / \mathrm{pl} \\
\text { experimental }\end{array}$ & $\begin{array}{c}\text { Sequence } \\
\text { coverage (\%) }\end{array}$ & $\begin{array}{c}\text { unique peptide } \\
\text { matched }\end{array}$ & score \\
\hline \multicolumn{10}{|c|}{ Up-accumulated spots in low quality oocytes (12) } \\
\hline 1 & 1324 & 1.1 & Vitellogenin [Crassostrea gigas] & AB084783 & $179.2 / 9.2$ & $20 / 6.2$ & 2.5 & 2 & 176.8 \\
\hline 2 & 1772 & 1.2 & Vitellogenin [Crassostrea gigas] & AB084783 & $179.2 / 9.2$ & $200 / 9.2$ & 9.9 & 14 & 902.8 \\
\hline 3 & 253 & 1.3 & Vitellogenin [Crassostrea gigas] & AB084783 & $179.2 / 9.2$ & $200 / 10.0$ & 12.1 & 13 & 841.1 \\
\hline 4 & 292 & 1.8 & $\begin{array}{c}\text { Vitellogenin [Crassostrea gigas] } \\
\text { Vitellogenin precursor [Crassostrea gigas] } \\
\text { Vitellogenin-2 [Crassostrea gigas] }\end{array}$ & $\begin{array}{l}\text { AB084783 } \\
\text { CX069168 } \\
\text { CU682295 }\end{array}$ & $\begin{array}{c}179.2 / 9.2 \\
25.0 / 9.2 \\
60.8 / 8.8 \\
\end{array}$ & $\begin{array}{l}90 / 10.0 \\
90 / 10.0 \\
90 / 10.0\end{array}$ & $\begin{array}{c}9.4 \\
12.3 \\
3.3 \\
\end{array}$ & $\begin{array}{c}14 \\
2 \\
2\end{array}$ & $\begin{array}{l}926.3 \\
143.0 \\
105.9\end{array}$ \\
\hline 5 & 371 & 1.2 & $\begin{array}{c}\text { Vitellogenin-2 [Crassostrea gigas] } \\
\text { Vitellogenin precursor [Crassostrea gigas] }\end{array}$ & $\begin{array}{l}\text { CU682295 } \\
\text { FP089745 }\end{array}$ & $\begin{array}{l}60.8 / 8.8 \\
21.9 / 9.7 \\
\end{array}$ & $\begin{array}{l}70 / 8.8 \\
70 / 8.8 \\
\end{array}$ & $\begin{array}{c}18.4 \\
9.0 \\
\end{array}$ & $\begin{array}{l}9 \\
2 \\
\end{array}$ & $\begin{array}{l}557.1 \\
302.2 \\
\end{array}$ \\
\hline 6 & 1780 & 1.8 & $\begin{array}{c}\text { Vitellogenin precursor [Crassostrea gigas] } \\
\text { Vitellogenin-2 [Crassostrea gigas] }\end{array}$ & $\begin{array}{l}\text { CX069168 } \\
\text { CU682295 }\end{array}$ & $\begin{array}{l}25.0 / 9.2 \\
60.8 / 8.8\end{array}$ & $\begin{array}{l}70 / 9.0 \\
70 / 9.0\end{array}$ & $\begin{array}{c}12.8 \\
2.0\end{array}$ & $\begin{array}{l}2 \\
1\end{array}$ & $\begin{array}{l}118.5 \\
114.7\end{array}$ \\
\hline 7 & 1802 & 1.3 & $\begin{array}{l}\text { Vitellogenin precursor [Crassostrea gigas] } \\
\text { Vitellogenin precursor [Crassostrea gigas] }\end{array}$ & $\begin{array}{l}\text { FP089757 } \\
\text { CX069168 }\end{array}$ & $\begin{array}{l}24.6 / 9.1 \\
25.0 / 9.2 \\
\end{array}$ & $\begin{array}{l}25 / 9.5 \\
25 / 9.5 \\
\end{array}$ & $\begin{array}{l}24.8 \\
10.6 \\
\end{array}$ & $\begin{array}{l}6 \\
1 \\
\end{array}$ & $\begin{array}{l}362.3 \\
360.8 \\
\end{array}$ \\
\hline 8 & 469 & 1.2 & $\begin{array}{c}\text { Isocitrate dehydrogenase [Crassostrea gigas] } \\
\text { Phosphoribosylaminoimidazole carboxylase [Bombyx mori] } \\
\text { Vitellogenin [Crassostrea gigas] }\end{array}$ & $\begin{array}{l}\text { CK172330 } \\
\text { AM866034 } \\
\text { AB084783 }\end{array}$ & $\begin{array}{c}50.3 / 7.9 \\
28.7 / 5.3 \\
179.2 / 9.2 \\
\end{array}$ & $\begin{array}{l}50 / 7.0 \\
50 / 7.0 \\
50 / 7.0\end{array}$ & $\begin{array}{c}14.4 \\
6.3 \\
2.5 \\
\end{array}$ & $\begin{array}{l}6 \\
3 \\
4\end{array}$ & $\begin{array}{l}383.1 \\
265.1 \\
264.2\end{array}$ \\
\hline 9 & 470 & 1.2 & Isocitrate dehydrogenase [Crassostrea gigas] & CK172330 & $50.3 / 7.9$ & $50 / 7.3$ & 28.8 & 10 & 668.7 \\
\hline 10 & 375 & 1.3 & ATP synthase subunit alpha [Bos taurus] & BQ426532 & $59.8 / 8.5$ & $70 / 7.2$ & 23.0 & 12 & 870.7 \\
\hline 11 & 712 & 1.2 & Dyp-type peroxidase [Schistosoma mansoni] & AM858788 & $41.4 / 8.2$ & $37 / 6.0$ & 7.9 & 10 & 688.9 \\
\hline 12 & 1440 & 1.1 & Cofilin [Schizosaccharomyces pombe] & AM854555 & $15.6 / 5.8$ & $15 / 5.6$ & 57.3 & 5 & 364.6 \\
\hline \multicolumn{10}{|c|}{ Up-accumulated spots in high quality oocytes (8) } \\
\hline 13 & 1729 & 1.3 & Vitellogenin [Crassostrea gigas] & AB084783 & $179.2 / 9.2$ & $40 / 8.8$ & 6.3 & 12 & 762.2 \\
\hline 14 & 336 & 1.1 & $\begin{array}{c}\text { Vitellogenin [Crassostrea gigas] } \\
\text { Heat shock } 70 \text { kDa protein cognate [Crassostrea gigas] }\end{array}$ & $\begin{array}{l}\mathrm{AB} 084783 \\
\mathrm{AF} 144646\end{array}$ & $\begin{array}{l}179.2 / 9.2 \\
72.0 / 5.38\end{array}$ & $\begin{array}{l}70 / 7.3 \\
70 / 7.3 \\
\end{array}$ & $\begin{array}{l}3.5 \\
3.4\end{array}$ & $\begin{array}{l}6 \\
2\end{array}$ & $\begin{array}{l}394.3 \\
119.5\end{array}$ \\
\hline 15 & 260 & 1.3 & Heat shock $70 \mathrm{kDa}$ protein cognate [Crassostrea gigas] & AF144646 & $72.0 / 5.38$ & $80 / 5.5$ & 24.4 & 16 & 1152.9 \\
\hline 16 & 332 & 1.1 & Disulfide-isomerase [Gallus gallus] & AM854930 & $55.5 / 5.7$ & $60 / 5.8$ & 15.4 & 6 & 432.5 \\
\hline 17 & 791 & 1.7 & $\begin{array}{l}\text { 14-3-3 protein epsilon [Drosophila melanogaster] } \\
\text { Proliferating cell nuclear antigen [Macaca fascicularis] }\end{array}$ & \begin{tabular}{|l|} 
AM854805 \\
EW779000
\end{tabular} & $\begin{array}{l}29.1 / 4.7 \\
28.7 / 4.6\end{array}$ & $\begin{array}{l}30 / 4.8 \\
30 / 4.8\end{array}$ & $\begin{array}{l}26.5 \\
37.6\end{array}$ & $\begin{array}{l}9 \\
9\end{array}$ & $\begin{array}{l}565.9 \\
531.8\end{array}$ \\
\hline 18 & 1723 & 1.4 & Cyclophilin [Homo sapiens] & FU6OSJA01BDE13 & $17.5 / 8.7$ & $15 / 9.5$ & 29.2 & 7 & 452.2 \\
\hline 19 & 1726 & 1.9 & Cyclophilin [Homo sapiens] & FU6OSJA01BDE13 & $17.5 / 8.7$ & $16 / 8.0$ & 6.7 & 2 & 128.6 \\
\hline 20 & 1434 & 1.8 & Cyclophilin [Homo sapiens] & FU6OSJA01BDE13 & $17.5 / 8.7$ & $15 / 9.2$ & 20.1 & 3 & 193.6 \\
\hline
\end{tabular}

